\title{
Uses of the Past in Early Medieval Iberia (Eighth-Tenth Centuries)
}

\author{
Jorge Elices Ocón and Eduardo Manzano Moreno*
}

During the Early Middle Ages, most of the Iberian Peninsula became part of the so-called dār al-Islam, the huge realm that extended from the shores of the Atlantic to the borders of the Indian subcontinent, and which comprised North Africa, the Near East and significant parts of Central Asia. In the long run, this meant a dramatic shift from the notions, ideologies and frames of reference that emerged in other western regions of the former Roman Empire. Notwithstanding this obvious divergence, Iberia had shared with these regions a common classical legacy that was assimilated, readapted and, finally, integrated after the Arab conquest under a new perspective in a number of distinctive ways. The aim of this paper is to analyse receptions, perceptions and ideas on classical Antiquity from the eighth to the tenth century in both al-Andalus and the Christian north, drawing data from the material evidence and the written record. It is our contention that the appreciation of this legacy underwent significant changes in both cultural milieus as a result of changing political and social circumstances.

Keywords: Reuse; translation; legitimation; Antiquity; Umayyad; Asturias, al-Andalus

\section{Introduction}

The way any given medieval society perceived its past is a good proxy for understanding not only its prevalent cultural traditions, but also the social and political traits that helped to build its definition of itself. Being a process of ideological elaboration, it involved not only historical writing, but also the preservation, readaptation, obliteration or neglect of existing remains that were, or were not, deemed relevant for prevailing identities. This was a complex endeavour, as any relation with the past involved a constant selection and/or disposal of texts, legacies or notions that helped to re-elaborate new-old ideas, which justified existing social or political identities. It is important to bear in mind, however, that not all medieval social formations considered history as a crucial element for legitimization, as there were alternative ideological elements that could also account for existing political or social orders: this helps to explain why there were certain medieval formations which showed little interest in the past, placing an stronger emphasis on religious, legal or political factors as the main arguments for their legitimacy.

* Correspondence details: Jorge Elices Ocón (corresponding author), Universidade Federal de São Paulo, jorge. elices.ocon@gmail.com, Rua Santo Antonio, 1046, 013014, São Paulo

Eduardo Manzano Moreno, Instituto de Historia CSIC-University of St. Andrews, eduardo.manzano@cchs.csic.es, Albasanz 26-28 Madrid 
In recent years, there has been a growing interest in this issue, as historians have become increasingly aware of the weight of the past (or its lack) in the configuration of the medieval body politic. The early stages of this process are particularly significant, as they highlight the wide range of ideological alternatives, which were at stake in the post-Roman period, and which were reshaped through a complex process of ideological elaboration that had long lasting effects in the late Middle Ages. In the case of Italy, for instance, the initial fields of urban ruins inherited from the Roman past in ancient cities went from being simple quarries for construction purposes to becoming landmarks that stimulated or created a sense of citizenship. ${ }^{1}$ A different path has been revealed by R. McKiterrick in her analysis of the early eighth century Liber Historia Francorum, which ascribed the origins of the Franks to a group of Trojans who took refuge by the Black Sea after the fall of their city: in this case, historical origins were also rooted in a past linked with Rome, but with the main aim of conveying "a sense of Frankish superiority even over the early Romans. «²

It is in the framework of this ongoing discussion that the case of medieval Iberia is particularly revealing. The abrupt separation between the Christian north and Islamic alAndalus also entailed a deep ideological divide that, as we will see, affected perceptions of their shared Roman legacy. The aim of this paper is to compare how these perceptions emerged by comparing them in a long-term perspective. Contrary to commonly held assumptions, however, we argue that there was not an "essential« opposition between both realms, but rather a changing pattern of perceptions, depending on a number of social and political circumstances. The following discussion is based not only on textual sources, but also on remains from Antiquity existing in early medieval Iberia, as we are convinced that both types of evidence reflect the same trends in the social and political construction of the past.

\section{The Early Period: a Past With and Without Meaning}

What were the material remains of the classical past in Iberia at the time of the Arab conquest in 711? There is considerable evidence that shows that the conquerors found a landscape that was punctuated by derelict buildings, abandoned public works and disused structures, which had been constructed in Roman times, but had suffered decay and transformations since then. The new Arab rulers dealt with this landscape in a number of different ways. Some structures were restored; other remains were re-adapted, whereas in some other cases ancient ruins and spaces were used in ways that bear witness of their long-lasting decline.

A good example of a classical structure that was refurbished by the Arab conquerors is the Roman bridge that crossed the Guadalquivir river in their new capital, Cordoba. This bridge had been built in the first century BCE and from its inception it had been conceived as an important strategic landmark, being the only stone bridge over this river, the most important watercourse of southern Iberia. According to textual sources, when the Arabs took over

1 C. La Rocca, »Using the Roman past «, 68 ,

2 R. McKitterick, History and Memory, 10. 
Cordoba, the bridge was in ruins and one of their first decisions was to reconstruct it. The decision may have been prompted by the necessity of having an unobstructed route connecting the new capital with the southern coast where the conquerors had originally landed, and sea contacts with North Africa and the caliphal metropoli were crucial at this early juncture. ${ }^{3}$

The adaptation of remains from the classical legacy is also visible in the case of Roman aqueducts. Again, Cordoba provides excellent evidence on this, as shown by the case of al-Rușāfa, a recreational property (munya) that was built by the amìr 'Abd al-Raḥmān I (755786) beyond the northern wall of the city. Archaeological works have shown that this munya had a hydraulic system that reused a previous Roman aqueduct, which had originally supplied water to classical Corduba. Other works undertaken in the ninth century readapted parts of the ancient water structures in order to supply water to the Umayyad palace and to the neighbouring main mosque, both of them located beneath the southern wall of the city. ${ }^{4}$

Evidence of the state of dereliction of former urban Roman sites at the time of the Arab conquest is also provided by early Islamic tombs laid in places that used to be fully functional in classical times. This is the case for three Islamic graves discovered in Nimes (southern France), the corpses in which belong to individuals who lived during the first half of the eighth century and were buried within the walls of the ancient Roman enclosure. In classical times, this area had been a quarter with a typical urban landscape, which had progressively changed into a zone of fallow lands after the third century CE. ${ }^{5}$ In Pamplona's Plaza del Castillo (Navarra), Muslim graves from this early period have also been discovered in an area that had been occupied by Roman thermae. ${ }^{6}$ Munigua (north of Seville) was a Roman city that flourished between the first and third centuries CE. Here, the excavation of the atrium of a house, which later became a workshop, has revealed the corpses of two Muslim individuals, also from this early period, who were placed into the pit with their right-hand side facing south-east in the direction of Mecca. ${ }^{7}$ Another fascinating case of Islamic burials in a former Roman site is Toledo's ancient circus, where a number of graves were discovered during archaeological excavations conducted during the last century, although in this case it is not possible to determine their chronology. ${ }^{8}$

This landscape of ruins and abandoned sites also provided spolia for the early constructions of the new rulers. The case par excellence is the main mosque of Cordoba, whose early phase was built in the 780 os and whose innovative arcaded prayer hall rests on Roman columns, capitals and cymatiums that had been extracted from classical buildings. The formal analysis of these materials reveals a long chronology (first to fourth centuries CE) that indicates a diverse provenance from different ruined Roman constructions located not only

3 Akhbär Majmü'a, 23-24, ed. Lafuente, 58-59; Fath al-Andalus, ed. Molina, 46 1. 37; Dhikr bilad al-Andalus, ed. Molina, 21, l. 37. On a local scale, the renewal of the Cordoban bridge allowed for a reconnection between both banks of the Guadalquivir, and this resulted in the growth of a new urban suburb, called Shaqunda, which emerged on the left side of the river, opposite the southern wall of the old ciuitas, Casal, Rabad of Shaqunda.

4 Murillo Redondo, Almunia de al-Rusafa; Ventura Villanueva, Acueductos romanos de Córdoba, 126; Pizarro Berengena, Abastecimiento de agua, 139-146.

5 Gleize et al., Early medieval Muslim graves.

6 Faro Carballa et al., Pamplona y el Islam, 238.

7 Eger, Frühislamische Bestattungen in Munigua, 260-261

8 Juan García, Enterramientos medievales, 641-654. 
in Cordoba but also in Mérida and Italica (near present-day Seville). One of the cymatiums, for instance, bears a Latin inscription that witnesses its original use as the pedestal of an equestrian statue of a fourth-century Roman governor. ${ }^{9}$ Other reused pieces may have evoked a different consideration. A fragment of a Roman sarcophagus of Christian derivation was reused in the foundation of one of the mosque's pillars. The piece was not visible, but the Christian figures were rudely mutilated with the exception of two carved in low relief. ${ }^{10}$ Another series of reused capitals in the mosque of Cordoba come from Visigothic buildings, some of them dated as late as the seventh century $\mathrm{CE}$, something that again hints at the very diverse origins of the buildings from which these spolia were taken. ${ }^{11}$

Reutilisation of Roman materials is also documented in Seville, where the earliest preserved Arab inscription in al-Andalus was engraved in the shaft of an ancient column and celebrated the foundation of the Ibn 'Adabbas mosque in the year 820-821 CE. There is also evidence of Roman columns with Arab graffiti from the ninth century CE in rural sites, such as the villae of Milreu (Estoi, Portugal), Casa Herrera (Mérida) or Carranque (Toledo). In all these sites, columns, which once had adorned perystili and main entrances to buildings, were now inscribed with pious invocations and Arabic names. Finally, there are also a number of Muslim epitaphia that were engraved using the reverse sides of ancient Roman gravestones. ${ }^{12}$

These examples of adaptations and reuses of classical remains show a strong emphasis on functionality rather than meaning. During the eighth and ninth centuries, rulers, builders or individuals utilized or readapted bridges, aqueducts, spolia, gravestones or former Roman sites in al-Andalus because they were useful or handy for specific purposes. It is not possible, though, to ascertain any ideological intentionality in these reutilizations beyond a generic purpose of cultural appropriation and historical superimposition. This is particularly evident in the case of the mosque of Cordoba, which follows earlier precedents in the Near East and North Africa, where ancient materials had also been reutilised in the prayer halls of the Umayyad mosque in Damascus and the mosque of Qayrawān. Apart from these intriguing cases, the absence of a clear ideological motivation in the use or adaptation of ancient remains reflects a widespread lack of interest in a centuries-old legacy whose original meaning had become widely incomprehensible. A ninth-century Arab governor of Mérida was impressed by the quality of the marble inscriptions that were scattered across this city, once the capital of the Roman province of Lusitania, but he was unable to find any Christian who could decipher their contents, except an old monk. ${ }^{13}$ In the eyes of the new rulers, the past provided quality and magnificent remains, which were useful and prone to be adapted to their purposes and ideological premises, but whose significance was far from being obvious.

9 Stylow, Nuevo gobernador, 426-428.

10 Fontaine, Sarcófago cristiano, 99; Sotomayor, Datos históricos, 105-106; García García, Reutilización y destrucción, 245-246, figs. 3 and 4.

11 Cressier, Chapiteaux de la grande mosquée, 318-319

12 Ocaña Jiménez, Cúfico hispano, 22-23; Barceló, Columnas arabizadas, 92-99; Gonzalo Maeso, Inscripción árabe; Barceló and Labarta, Inscripción árabe, 201.

13 Torres Calzada, Emeritense, 243-244. 
This ignorance of or indifference to the meaning of the classical legacy was not limited to material remains. Neglect of the classical past at a period dominated by fresh and novel ideas coming from the East can also be discerned in the bitter words of Alvarus of Cordoba (d. 861), a scholar who complained about his fellow young Christians, who were more interested in the works of Arab writers than in the study of Latin. ${ }^{14}$ Alvarus was a contemporary of 'Abd al-Malik b. Habib (d. 853 CE), the author of the first work on history written in Arabic in al-Andalus that has come down to us. 'Abd al-Malik was born in the Andalusi province of Elvira, but had also travelled to Egypt and the Middle East. Once he was back in Cordoba, he was appointed senior legal advisor (mushāwar) of the Umayyad amir and became an influential figure who wrote a considerable number of works on Islamic law and theology. His "Book of History « (Kitäb al-Ta' rìkh) is an ambitious universal history, which starts with the creation of the world and includes a history of the pre-Islamic prophets and a sketch of prophet Muhammad' s mission. ${ }^{15}$ This is followed by a history of the caliphs and an account of the conquest of al-Andalus, which includes a list of its governors. Apocalyptic predictions about the imminent arrival of Judgement Day also figure prominently in this salvational history. Some of these prophecies were gathered by this scholar himself, but some others were written down by one of his disciples, who penned the only manuscript of this work that has survived to the present day ${ }^{16}$. Despite the fact that this was a work on »history", there was no mention of the classical past. In the cultural milieu of 'Abd al-Malik b. Habib, sources of knowledge and legitimacy were not to be found in the Graeco-Roman legacy and even less in the historical accounts of the Roman Empire, but rather in the Muslim tradition conveyed by the oriental Muslim scholars whom he had met during his travels.

The perceptions prevalent in al-Andalus in this early period bear a paradoxical comparison with the historical views that can be assessed in the Christian north. Here, the kingdom of Asturias had emerged in the aftermath of the Arab conquest in a territory that had been much less Romanized than the south, and therefore lacked the relatively dense urban network that the Arabs had inherited from Roman times. Ancient material remains were not so rife in Asturias and, consequently, their reuse in buildings of the eighth and ninth centuries, although not completely absent, was very scarce and limited. ${ }^{17}$ One example is the church of Santa María de los Arcos de Tricio (La Rioja), whose walls were built with reused material, and which had large Roman grooved tambours of columns, arranged irregularly in its aisles, as they had probably been taken from a building plundered at the nearby Roman city of Tritium Magallum. ${ }^{18}$

Albarus, Indiculus Luminosus, in Corpus Scriptorum Mozarabicorum, 314-315.

Ibn Habīb, Kitāb al-Ta' rīj, ed. Aguadé.

Ibn Habīb, Kitāb al-Ta' rīj, introd. Aguadé, 74-75, 87-10o.

Utrero Aguado and Sastre, Reutilizando materiales, 318 and 321.

Sáez Preciado, Últimas actuaciones realizadas; Utrero Aguado and Sastre, Reutilizando materiales, 315. 
For people living in northern Iberia, the Islamic conquest of Iberia had meant a clear rupture. The Visigothic kingdom was considered finished, and the legitimacy of the new kingdom initially relied on its military victories. ${ }^{19}$ During the last decades of the ninth century, social and political conditions changed dramatically in this region, as indigenous structures disintegrated under the aegis of the new kingship that had emerged as a result of the confrontation with the Muslims. The most striking feature of this kingship is that, despite the fact that it was rooted in local lineages, the kings of Asturias presented themselves as successors of the Visigothic kings, sporting the same set of Christian beliefs and values that had been defeated in $711 .^{20}$

The claim that the kings of Asturias were the inheritors of the defeated Visigothic kingship involved an ambitious programme of historical writing that was in full swing in the royal capital, Oviedo, by the 880 s, three decades after the death of 'Abd al-Malik b. Habib in Cordoba. One of the outputs of this endeavour was a wide-ranging historical chronicle, known today as the Chronicle of Albelda. This remarkable work opens with a miscellaneous section, which includes a terse but meaningful description of the world in general and Hispania in particular, as well as a section which describes the main traits of different peoples (Fortia Gotorum, Yra Britanie, Libido Scottorum, etc.). In the writing of these sections the author of the Chronicle of Albelda relied heavily on works from the late antique tradition, like the Cosmographia of Julius Honorius, a Roman writer who had probably lived in the third or fourth century, or the Etymologiae of Isidore of Seville (d. 636). ${ }^{21}$

The proper historical section of the chronicle begins with an estimation of the time passed since Creation, which amounts to a total of 6092 years. This calculation is probably based on the work of the Visigothic writer, Julian of Toledo (d. 690), whose De comprobatione sextae aetatis aduersus iudaeos had attempted to refute Jewish allegations that the Messiah had not yet been born, by showing that biblical chronology conclusively backed Christian claims to the contrary. The six millennia of human history are divided by the anonymous author into six ages from the time of Adam up to his day with the sixth age beginning with the birth of Christ, so that 883 years have passed since then. ${ }^{22}$ Within this chronological framework, the historical events described by the Chronicle of Albelda start with the foundation of Rome by Romulus and Remus and cover the deeds of the Roman emperors, including those of Constantinople until Emperor Leontios (695-698). ${ }^{23}$ This is followed by a history of the Visigothic kingdom until the defeat by the Arabs of their last king, Rodrigo. The last sentences of this section make it clear that the anonymous author viewed events in Iberia as the final outcome

19 Annales Portucalenses Veteres attested that the Visigothic kings were expelled from Hispania (expulsi sunt de regno Hispanie): in David, Annales portucalenses veteres, 291-292. The same idea (the end of the Visigothic kingdom) is mentioned in the Testamentum regis Adefonsi II, 87-88. Alfonso II declared Charlemagne's vassal in a letter: Einhard, Vita Caroli, 16, in Scriptores rerum Germanicarum, XXV, 19; Gil Fernández et al., Crónicas asturianas, introd. 73.

20 Regarding this new legitimacy as successors of the Visigothic kings: Gil Fernández et al., Crónicas asturianas, introd. 43-105; Isla Frez, Consideraciones and Monarchy and Neogothicism; Escalona, Family memories, 229-232.

21 Chronicle of Albelda, I-VIII, in Gil Fernández et al., Crónicas asturianas, 153-155.

22 Chronicle of Albelda, IX-X, in Gil Fernández et al., Crónicas asturianas, 155-156. De comprobatione, in Sancti Iuliani, ed. Hillgarth, I, 141-212.

23 Chronicle of Albelda, XIII, in Gil Fernández et al., Crónicas asturianas, 158-166. 
of the grandiose historical account he had undertaken: the "Sarracens « were still in possession of most of Spania, but Christians were fighting them daily until divine predestination would decree their expulsion: Sarraceni euocati Spanias occupant regnumque Gotorum capiunt, quem aduc usque ex parte pertinaciter possedunt. Et cum eis Xrniani die noctuque bella iniunt et cotidie confligunt dum predestinatio usque diuina dehinc expelli crudeliter iubeat. Amen. ${ }^{24}$

The comparison of these two historical perspectives is dazzling. Whereas 'Abd al-Malik b. Habib conceived the history of the world as a succession of prophetic missions, which culminated with Muhammad and the Islamic expansion, the author of the Chronicle of Albelda used computations based on the Bible in order to draw an historical account that viewed the past as a succession of eras, which framed the rules and deeds of Roman and Visigothic kings and emperors (e.g. Adrianus rg. an. XXI. Iste Iherosolimam restaurauit et ex nomine suo Eliam uocitabit). This culminated with the bold efforts undertaken by the Asturian kings to expel Muslims from Iberia. Both historical approaches were salvational and based on a linear conception that considered the world as framed into a limited span of time previously decreed by God. ${ }^{25}$ However, their approach was very different: whereas 'Abd al-Malik b. Habīb's was a history of prophecy culminating with the revelation received by Muhammad, the Chronicle of Albelda was a militant view of human history, which considered chronology as a hint of a divine plan that was unfolding in the course of time and supported the legitimacy of the kings of Asturias. 'Abd al-Malik b. Habìb was writing in a social milieu that was embarked on a process of religious Islamization, a perspective that needed no references to the classical past. In contrast, the author of the Chronicle of Albelda had the crucial mission of convincing his audience that the events that were taking place in the remote lands of northern Iberia were unfolding according to a divine plan. It is also significant that in both cases predictions about the future became part and parcel of perceptions about the past. In the case of 'Abd al-Malik b. Habỉb and his continuators these eschatological predictions foresaw tough times for the Muslim community before Judgement Day; in the case of the writers who worked in the kingdom of Asturias at the end of the ninth century, prophecies were used to assert confidence on a rapid victory of Christians over the Muslims and the restoration of Christianity.

\section{The Umayyad Caliphate: Searching for a New Antiquity Discourse}

The optimism of the author of the Chronicle of Albelda, who was writing in the 880s, was well justified. During the second half of the ninth century there had been widespread rebellions against the rule of the Umayyad amirs in al-Andalus. These rebellions were led in most cases by descendants of the old Visigothic aristocracy, who had converted to Islam in the aftermath of the conquest - the so-called muwalladün - but were reacting against the increasing centralization and tax pressure that the Umayyad rulers had imposed during the previous decades. Social change was gradually fostering a more urbanized tributary society in al-Andalus that was also resisted by these muwalladün, whose power base had remained mainly rural and rested upon ties of dependence. The possibility of an extinction of the Umayyad dynasty and a termination of Islamic rule in Iberia was very real indeed.

24 Chronicle of Albelda, XIV, in Gil Fernández et al., Crónicas asturianas, 171. An alternative version of this last sentence preserved in another manuscript is less optimistic: Et cum eis Xrniani die noctuque bella iniunt et cotidie confligunt sed eis ex toto Spaniam auferre non possunt. Finit. On the sources of this writer: Gil Fernández et al., Crónicas asturianas, 91-98.

25 Marsham, Universal histories, 437-439. 
Despite having been on the brink of being overthrown, during the first decades of the tenth century the Umayyads made a spectacular comeback. After a series of tireless military campaigns, the new amir 'Abd al-Rahmān III (912-961) managed to subdue all rebellions against his rule. In this he was helped by the profound changes that Andalusi society had been undergoing in the previous decades. The gradual but unstoppable processes of social Arabization and Islamization had produced a more homogeneous society with an urban drive that favoured the imposition of a centralized state. ${ }^{26}$ In 929, just after having finally defeated the Banū Ḥafsūn, who had been the most outspoken muwalladūn rebels against his dynasty, 'Abd al-Raḥmān III proclaimed himself as caliph.

This proclamation had a remarkable religious and political dimension within the Islamic world. First of all, it sent a clear message to the rival Shi'ìte dynasty of the Fātimids, who had just proclaimed themselves caliphs in North Africa in 909, and were challenging Umayyad rule as direct descendants of the prophet Muhammad, his daughter Fātima and his son in law 'Alī. With his own promotion to the caliphal title, 'Abd al-Rahmān III was trying to recover the legitimacy and authority of his ancestors, the Umayyad Caliphs of Damascus, by being recognized as the leader of the Sunnite community. ${ }^{27}$ However, the proclamation also had an internal dimension. In one of his official letters, 'Abd al-Raḥmān III insisted on the necessity that "people were a single community, obedient, calm, subdued and non-sovereign, governed and non-ruling ${ }^{28}$. The ideology behind this bold assertion of authority was mainly pragmatic. Lacking the formidable genealogy of the Fătimids, the Umayyad caliphs underlined that theirs was a dynasty that had managed to preserve Muslim tradition within the limits of strict orthodoxy, something that had entailed prosperity and security for its subjects in al-Andalus.

The pragmatism of Umayyad ideology went hand in hand with a new historical discourse, which stressed the necessity of a more inclusive perception of the past in contrast with the previous divisions that had been rife during the former period. Processes of social Islamization and Arabization had encountered resistance in some sectors, as we have just seen, but the new caliphal era fostered a comprehensive narrative that insisted on the homogeneity of the community in al-Andalus, despite the well-known fact that it included groups from diverse origins. Umayyad legitimacy drew mainly from principles taken from the Sunnite Islamic tradition, but its new pragmatic formulation also needed elements from a classical tradition that, as it emerged, could also provide valuable arguments supporting Umayyad claims. ${ }^{29}$

This is why, for the first time in several centuries, late classical works became a reliable source for Arab authors historical writing during the tenth century. It meant an actual "revolution" in the Iberian Peninsula since most of the information gathered until then by Arab authors in al-Andalus had come from Quranic and Oriental traditions, as we have already seen. In this new ideological framework, classical sources were selected, translated, compared and complemented with local traditions and Oriental sources, in order to create a more complete and ambitious historical narrative that focused on the Iberian Peninsula as the

26 Acién, Entre el feudalismo; Manzano, Conquistadores, emires y califas.

27 Martínez-Gros, L'idéologie omeyyade; Acién, Materiales e hipótesis, 189; Safran, Second Umayyad Caliphate; Fierro, Madinat al-Zahara', 316-321.

28 Ibn Hayyān, Muqtabis V, ed. Chalmeta et al., 142 and 155.

29 Vallvé, Fuentes latinas, 258-270; Picard, Passé antique, 98-99; Elices, Pasado preislámico, 43-74. 
cradle from where the triumphant Umayyad legitimacy had fought its way back in order to claim authority over the whole Muslim community. In this new ideological landscape, Arab authors recovered ancient historical figures, such as Hercules, Viriathus, Julius Caesar, Octavius Augustus, or even Visigothic kings, like Leovigild or Recared who, according to their accounts, would have founded or built several cities and monuments still visible in al-Andalus. In the tenth century, for the caliphs Antiquity definitely became something that went beyond mere curiosity, convenience or interest, to signify, in particular, precedence and legitimacy.

Two works highlight this significant change: the Kitäb Hurūshiyūs and the Ta'rìkh fi akhbär mulūk al-Andalus (History of the kings of al-Andalus) by Aḥmad al-Rāzì (d. 955). Both works were written in the Umayyad court and elaborated a powerful historical narrative that is also reflected in archaeological evidence that has discovered a set of classical statues and sarcophagi reused in the palatine city of Madinat al-Zahrä', construction of which had been ordered by 'Abd al-Raḥmān III in c. 936.

\section{The Kitāb Hurūshiyūs: a Unique Translation}

The Kitäb Hurūshiyūs is an extraordinary work for a number of reasons. This is the only translation of a Greek or Latin historical work written in Late Antiquity that is documented in a medieval Islamic society. It is well known that in the Bayt al-Hikma (House of Wisdom) in Baghdad, classical texts were widely translated, but these were philosophical or scientific works, as pre-Islamic history seems not to have been a matter of particular interest at the court of the 'Abbāsid caliphs. ${ }^{30}$ The Kitāb Hurūshiyūs has survived in a single manuscript held at Columbia University (New York), which is incomplete. However, thanks to its index, it can be asserted that this work was not only a translation of Adversus paganos historiarum libri septem by Paulus Orosius (d. 420); it also included events that had occurred in the East until Emperor Heraclius and also those connected to the conquest of Hispania by the troops of Țāriq b. Ziyād. ${ }^{31}$

The circumstances that surrounded the translation of the work by Paulus Orosius are mentioned by two Arab authors: Ibn Juljul (d. c. 994), and Ibn Khaldūn (d. 1406). The former states that Orosius' work was sent to the caliph 'Abd al-Rahmān III as part of a gift sent in 948-949 by the Byzantine emperor, Romanus Lecapenus, along with a Greek copy of the book of Dioscorides, De Materia Medica, in one of the frequent diplomatic exchanges between both courts..$^{32}$ This may well be a watered-down version of actual facts, since Orosius was known in Iberia and the Adversus paganos is included in the catalogue of a Christian library in Cordoba. ${ }^{33}$

Rosenthal, Classical Heritage, 24-28; Gutas, Greek Thought, Arabic Culture, 107-150; Di Branco, Storie arabe, 9-36. Levi della Vida, Traduzione araba; Molina, Orosio y los geógrafos, 66-71; Daiber, Orosius »Historiae adversus paganos«; Kitāb Hurūšiyūs, ed. Penelas, 27-66; Sahner, From. Augustine to Islam, 909.

2 Ibn Ŷulŷul, Tabaqāt al-ațibba, cited after Molina, Orosio y las geógrafos, 67.

Kitāb Hurūšiyūs, ed. Penelas, 40-42. Orosius' work was widely known in the Carolingian Empire where manuscripts containing his work were prominent in ninth-century library catalogues, McKitterick, History and Memory, 46. This work does not seem to have been used by the author of the Chronicle of Albelda, though. 
Be that as it may, Ibn Khaldūn further adds that the work was translated »for the Umayyad al-Ḥakam al-Mustanșir [al-Ḥakam II] by the qā Penelas has suggested that the judge of the Christians can be identified with Hafș b. Albar alQūṭi, who was also the translator of Christian texts into Arabic. Next to him, Qāsim b. Aṣbag supervised the Arabic translation. He was an Umayyad client (mawlà) who had been the mentor of both caliph 'Abd al-Raḥmān III and of his son and successor, al-Hakam II (961-976). ${ }^{35}$

As has already been mentioned, Ḥaf̣̦ b. Albar al-Qūṭī and Qāsim b. Așbag did not produce a mere translation, but a proper chronicle which added other texts designed to continue the account of the late Roman author. It is significant that some of these texts were the same ones that had been used by the chroniclers working in the kingdom of Asturias several decades earlier: the Cosmographia of Julius Honorius, the works of Isidore of Sevilla or the writings of St. Jerome, which provided specific references about the Roman emperors, the history of the Christian Church or later events leading to the Islamic conquest of Iberia. Certainly, the list of sources and the extension of the history clearly point out the magnitude of the translation carried out. ${ }^{36}$

Why spend time and resources in such a major project? The question still demands an answer. Since at least one translator was a Christian, Mayte Penelas considers the Kitäb Hurūšiyūs a by-product of the increasing Arabization of the Christian community at Córdoba, which was in dire need of a universal history in Arabic but written from a Christian point of view, due to the general decline in the use of Latin among members of this community ${ }^{37}$. This hypothesis does not contradict the idea that the translation was sponsored by the caliphal court, as is clearly stated by both Ibn Juljul and Ibn Khaldūn.

The Kitāb Hurūšiyūs was in all probability housed in the splendid library of Caliph alHakam II, alongside manuscripts dealing with Islamic law and theology, and presumably close to a translation into Arabic of a summary of the Talmud that we know was also kept in that library. David Wasserstein has rightly suggested that this diversity in library contents responded to a conscious attempt to rival Baghdad, the distant capital of the adversaries of the Umayyads, the 'Abbāsid caliphs. At a time when most of the population had converted to Islam, the "numbers of people involved or expecting to be involved in the majoritarian culture of [al-Andalus] were vastly greater than ever before« and this gave the Umayyads the opportunity to seek a distinctive legitimization that could be distinguished from the one sported by the oriental caliphs. This legitimization was not to be only Arab and Islamic, as al-Andalus also reckoned with traditions pertaining to different social groups which had been recently incorporated into caliphal rule, thus broadening its social base. In this connection, Wasserstein considers that the "tremendous vitality" of the Jewish community in caliphal Cordoba reckoned "with the tacit blessing of the state", as demonstrated by the fact that its main promoter, the great Jewish physician and scholar, Hasday b. Shabrūt (915-975), was an official of the caliphal government. Behind this policy lay a conscious attempt to appropriate 
the cultural heritage of Judaism as an integral element "in the creation of a new view of alAndalus «. ${ }^{38}$ It is our contention that the Kitäb Hurūšiyūs served the same design, in this case regarding the pre-Islamic history of al-Andalus that was well known to Christian groups that had recently converted to Islam. The big challenge faced by Umayyad ideologues was how to incorporate these historical traditions into the narratives that legitimized their dynasty. This was the challenge that was taken on by the great historian, Aḥmad al-Rāzì (d. 955).

\section{Ahmad al-Räzī: a Historian with a Mission}

The translation of Orosius predated the historical chronicle that was composed by Ahmad al-Rāzì a few years later. As a matter of fact, the Kitāb Hurūšiyūs was one of his sources. As a general history centred on the Iberian Peninsula, the work of Aḥmad al-Ràzì is unique and somehow "visionary". It is divided into three main sections: a geographical description of the Iberian Peninsula, a pre-Islamic history of this land and a history of al-Andalus after the Islamic conquest. Therefore, he adopted a significant scheme within the early medieval historiography, because al-Ràzì focused his attention on the Iberian Peninsula as the historical subject of his work.

The importance of al-Rāzìs work contrasts with the problems of its transmission. No original manuscript has reached our days and, therefore, we can only rely on the wide transmission of this work, reaching four literary traditions (Arabic, Latin, Portuguese and Spanish) from the tenth to the seventeenth century. Apart from the Arab compilers, who drew on significant parts of the text of al-Ràzī, the most important of these works is the Crónica del Moro Rasis, a fifteenth-century Castilian translation of a Portuguese version of the original, which was commissioned by King Dinis (1279-1325). ${ }^{39}$ This tortuous transmission has given rise to a decades-long debate among scholars concerning what was the actual narrative of the pre-Islamic history of Iberia elaborated by al-Rāzì. However, the comparison between Rasis and quotes from later Arabic authors points out that the Castilian translation contains significant parts of the original work by the Cordoban historian. ${ }^{40}$

The Ta'rij fi ajbär mulük al-Andalus can be compared with the Chronicle of Albelda with which it shares some features, as both works include a geographical introduction and a history of Rome and the Visigothic kingdom. However, the work of Ahmad al-Rāzì is much more ambitious. It includes the history of pre-Roman Iberia and gathers more information than the Asturian chronicle. From what we know about the text of al-Rāzì, it is clear that the "Arab Orosius" was one of its main sources. However, the Cordoban historian also gathered information from the Chronicle of St. Jerome, the works of Isidore of Seville, the chronicle of John of Bíclarus, the Chronicle of 754 or even the work of Titus Livius. Furthermore, al-Ràzī not only considered these sources, but he also incorporated several new details from local traditions, memories and archaeological finds of inscriptions and statues. ${ }^{41}$ 
An episode of the Roman history of Iberia is a good example of how Aḥmad al-Rāzì elaborated on his sources in order to create a new narrative of the past that could explain and legitimize his present context. The account concerns Viriathus, the leader of the Lusitanian people who resisted Roman conquests in western Iberia during the second century BCE and was mentioned by Roman authors like Titus Livius or Florus. Viriathus is also mentioned in the Kitāb Hurūšiyūs in a correct translation of the original work by Orosius. However, in alRāzì’s work, these historical events take a different twist. Viriathus (Birbāț) is a rebel from Lusitania (Luyidānia) from Mérida (Mãrida), who takes control of Toledo and manages to defeat the Roman armies until he is finally betrayed by his own men. After the death of Viriathus, the uprising continues until, thanks to a new betrayal, the Romans manage to take control of the city. However, this is not the end of the rebellion of Toledo: a local chieftain called Antonius leads a new revolt and defeats the Romans again. Even Julius Caesar is forced to besiege the city, but he is forced to withdraw and returns to Rome defeated and humiliated. ${ }^{42}$

The narrative of Ahmmad al-Rāzì is obviously wrong and fabricated (Viriathus never rebelled in Toledo, there is no other evidence regarding Antonius, and Julius Caesar never besieged Toledo). The whole account is a deliberate invention of the past that combines certain historical references and figures with some topoi in order to draw a comparison between past and present Iberia. People of al-Rāzīs generation had strong memories of the uprisings that had unfolded in al-Andalus before caliphal rule and the figure of Viriathus displayed a striking similarity to rebels against Umayyad rule. By reinforcing this association between the past and the present, the author is trying to elaborate two points. On the one hand, the bellicose and insubordinate attitude of the people from Hispania is a major factor that has conditioned the dominance over the Iberian Peninsula over the centuries. On the other hand, Ahmad al-Rāzì is trying to reinforce Umayyad authority by elaborating a narrative that leads to the final triumph of 'Abd al-Rahmmān III against the rebels, thereby placing him as the only ruler capable of subduing and pacifying Toledo as well as al-Andalus. ${ }^{43}$

\section{Reuse in Madinat al-Zahrä': Memories in Stone}

While Aḥmad al-Rāzì was busy composing his monumental history of al-Andalus, Caliph 'Abd al-Rahmmān III had in 936 started the construction of a new palatine city called Madinat al-Zahra', which was located four kilometres west of Cordoba. The archaeological remains of this city speak of its magnificence and grandeur and they count among the finest examples of Islamic architecture of the period. But Madinat al-Zahrä' also housed a set of antiquities that were located in different parts of the city: twenty-five Roman sarcophagi, some of them really exceptional, and a number of statues that, although smaller, are no less important. ${ }^{44}$

42 Orosius, Historiae V, 4, 1-5, 12-4 and 7, 1-18, ed. Arnaud-Lindet; Kitäb Hurūšìūss, ed. Penelas, 255 and 257, fn 5-7, 10 and 12 and 262-3, fn 28-32; al-Rāzī, Crónica del moro Rasis, ed. xxx, 157-163; Ibn Ḥayyān, Muqtabis V, ed. Chalmeta et al., 180-181 and 206-207.

43 Elices, Pasado preislámico, 450-457.

44 Beltrán, Colección arqueológica, 109; idem, Hermeraclae hispanos; Beltrán et al., Sarcófagos romanos, 126-144; Vallejo, Ciudad califal, 178, 236-242, 262-263; Calvo, Madinat al-Zahra', observación; idem, Ciencia y adab; idem, Reuse of classical Antiquity. 
The main problem that arises from the study of this collection of antiquities is the state in which they have been found. The sarcophagi and the statues are almost completely destroyed, probably as a result of the looting of the city in the year 1010 during the civil war that brought an end to the Umayyad caliphate. ${ }^{45}$ However, it has been possible to reconstruct some of these sarcophagi and even to restore them to their original location in the courtyards of the residences: they functioned as basins and water sources, as demonstrated by the fact that they had been polished, partially restored with stucco and had holes in their sides. ${ }^{46}$

The function of these reused sarcophagi was eminently decorative and aesthetic. Some of them displayed splendid figurative scenes of ancient myths. However, their considerable number, their quality and the fact that they were placed in significant locations of palatine buildings may also indicate that their use had other ideological readings. Following this idea, S. Calvo Capilla has put forward the hypothesis that these sarcophagi could be linked to certain spaces devoted to knowledge at Madinnat al-Zahrā', where they would have been considered as "allegories of the sciences of Antiquity « ${ }^{47}$ This hypothesis, although certainly appealing, obviates the wide distribution of sarcophagi (and statues) throughout the entire palatine city, and their private and public use, as has been rightly pointed out by A. Vallejo. ${ }^{48}$

When analysed from the perspective that we are proposing in this paper, the process of searching out, selection, and collection of antiquities by the Umayyad caliphs seems to coincide with the same perception of the past that was being fostered by authors like Ahmad alRàzì. The reuse of classical remains like sarcophagi and statues should not be understood as a passive process of reception, not even as an »Antiquity revival«, but as an active process of appropriation and reinterpretation, linked to the new cultural memories and identities that the Umayyads were trying to foster. Sarcophagi and statues were not just simple spolia, but an extraordinary example of antiquarian and pre-musealization practices, according to the interpretation suggested by Wendy Shaw, who has stated the narrative and didactic purpose of this type of reuse in the Islamic world. ${ }^{49}$

Following these ideas, we consider that these antiquities had a clear purpose and meaning for those who contemplated them. There is a precedent for this in the Pharaonic statues and antiquities that were sent to Damascus after the conquest of Egypt and became part of the collection of the Umayyad caliphs in Damascus. 'Umar II (717-720) used to show this collection to his guests, explaining for them that these statues would actually be human beings petrified as a divine punishment for the sins of the pharaoh who had dared to confront Moses. ${ }^{50}$

45 Beltrán, Colección arqueológica, 111; Vallejo, Ciudad califal, 262, n. 92.

46 Beltrán, Colección arqueológica, 111-113 and Lam. I, 2; idem, Sarcófagos romanos, 37; Vallejo, Ciudad califal, 236-237 and 262-263, fig. 208.

47 Calvo, Madinat al-Zahra' observación; idem, Ciencia y adab; idem, Reuse of classical Antiquity. She focuses on references to the peninsular pre-Islamic past and its ruins, and highlights the translations and Caliph al-Hakam II' bibliofilia. When she actually centres the topic on the sarcophagi, the ideas pointed out just stress that at least two of the sarcophagi contain representational muses and philosophers that should be related to the astrological knowledge at that time.

48 Vallejo, Materiales de la Antigüedad.

49 Shaw, Possessors and Possessed, 38-39; Schnapp et al., World Antiquarianism.

50 Al-Maqrizī, Al-Khițat, I, 110; El Daly, Egyptology, 41-42. 
Therefore, it is clear that these remains were prone to carry certain stories, memories, and identities loaded with a certain meaning. In this connection, the antiquities at Madinat al-Zahrä' should be understood as archetypes of good and bad virtues, or as models or counter-models to be or not to be imitated, very much in the same way as Viriathus had been a past figure, who exemplified the evil nature of rebels finally subdued by the Umayyad caliph. In the same way that Toledo was now part of a community that was "governed and nonruling", antiquities collected by the Umayyad caliphs in their palatine city also stated that their power, conquests, and appropriations had bred a distinctive political identity.

\section{Conclusion}

This original and powerful discourse set by the Umayyad caliphs rapidly disappeared after the fall of the dynasty in 1031. Since it was a perception that was built from and for the present service of caliphs and state apparatus, the discourse it enshrined did not have any chance of survival once the caliphate finally collapsed. Al-Andalus fragmented into small taifa kingdoms and later Arabic authors were not particularly interested in the history of the Iberian Peninsula, as they rather focused on their kingdoms and cities, and on the literary aspects related to the $a d a b$ culture. History became less appreciated and later authors limited themselves to compiling the information elaborated by caliphal writers.

Interestingly, the Christian narrative that had also relied on Antiquity in order to build an ideology that could legitimize the rule of the kings of Asturias and the constant warfare against the Muslims also vanished after its sudden emergence in the late ninth century. Certainly, medieval Christian kings saw themselves as successors of the Visigoths who were aiming at the recovery of a lost land, but their claim came to be based more on religious grounds than on a clear elaboration of political legitimacy (fragmentation of the Christian north may also have been a reason that prevented this). The libraries of Iberian monasteries during the tenth and eleventh centuries were full of patristic works, religious commentaries and monastic rules, but works from Antiquity were notably absent in the manuscripts that were gathered within their walls.

Several new works on ancient history were elaborated after the end of the tenth century, such as the Chronica gothorum pseudo-isidoriana, a work dated in the first half of the twelfth century, written in Latin, but relying on the information gathered by Arabic sources. Like the Chronicle of Albelda or the work of Ahmad al-Ràzī, it also starts with a geographical description of Iberia, followed by the primitive kings of Rome, the emperors and the Visigothic kings, concluding with the Islamic conquest. However, although the Chronica gothorum pseudo-isidoriana included new details, such as a better description of the northern coast of Iberia or the legend of Romulus), it seems that it was an abbreviated version of Ahmad al-Rāzì's work put together with other Latin materials, without being able to convey fully its message. ${ }^{51}$

It was only in the thirteenth century when a renewed interest on the history of Iberia produced works such as the Historiae Rebus Hispaniae of the archbishop Jiménez de Rada (1170-1247) and the Estoria de España of Alfonso X (1221-1284). Like Ahmad al-Rāzī, they place Iberia as the centre/subject of their historical narratives ${ }^{52}$. It is probably no coincidence that the former was familiar with his work. ${ }^{53}$ 


\section{Acknowledgements}

This work was supported by the FAPESP, under Grant 2018/15102-7; FAPESP-BEPE 2019/11019-0: relying on the work developed for a PhD project under Grant FPU12/03709. 


\section{References}

Acién Almansa, Manuel, Entre el feudalismo y el islam. Úmar ibn Hafșun en los investigadores, en las fuentes y en la historia (Jaén, 1994).

Acién Almansa, Manuel, Materiales e hipótesis para una interpretación del Salón de Abd al- Rahman al-Nasir, in: Antonio Vallejo (coord.), Madinat al-Zahara. El Salón de Abd al-Rahman III (Córdoba, 1995) 177-195.

Akhbār Majmü’a, Crónica anónima del siglo XI, ed. Emilio Lafuente Alcántara (Madrid, 1867). English translation: David James, A History of Early Al-Andalus. The Ajbär maŷmü'a. A Study of the Unique Arabic Manuscript in the Bibliotheque Nationale de France, Paris, With a Translation, Notes and Comments (London, 2012).

Albarus, Indiculus Luminosus, in Corpus Scriptorum Mozarabicorum, ed. Juan Gil (Madrid, 1973). Alfonso X The Wise, General estoria, ed. Pedro Sánchez Prieto Borja, 2 vols (Madrid, 2001).

Alfonso X The Wise, Primera crónica general, ed. Ramón Menéndez Pidal, 2 vols (Madrid, 1977).

Barceló, Carmen, Columnas arabizadas en santuarios del Occidente islámico, Cuadernos Emeritenses 17 (2001) 87-137.

Barceló, Carmen and Ana Labarta, Inscripción árabe en la ermita de Nuestra Señora de la Vega (Torre de Juan Abad, Ciudad Real), Vínculos de Historia 8 (2019) 216-231.

Beltrán Fortes, José, La colección arqueológica de época romana aparecida en Madinat al-Zahra, Cuadernos de Madinat al-Zahra 2 (1988-1990) 109-126.

Beltrán Fortes, José, Hermeraclae hispanos, in: Estudios dedicados a Alberto Balil. In memorian (Málaga, 1993) 163-174.

Beltrán Fortes, José, Los sarcófagos romanos de la Bética con decoración de tema pagano (Málaga, 1999).

Beltrán Fortes, José, Miguel Ángel García and Pedro Rodríguez Oliva, Los sarcófagos romanos de Andalucía. Corpus de esculturas del Imperio Romano (Murcia, 2006).

Calvo Capilla, Susana, Ciencia y adab en el islam. Los espacios palatinos dedicados al saber, Anales de Historia del Arte 23/II (2013) 51-78.

Calvo Capilla, Susana, Madinat al-Zahra' y la observación del tiempo. El renacer de la Antigüedad Clásica en la Córdoba del siglo X, Anales de Historia del Arte 22/II, (2012) 131-160.

Calvo Capilla, Susana, The reuse of classical Antiquity in the palace of Madinat al-Zahra' and its role in the construction of Caliphal legitimacy, Muqarnas 31/1 (2014) 1-33.

Casal García, María Teresa, The rabad of Shaqundain Umayyad Cordoba (750-818 AD), in: Sabine Panzram and Laurent Callegarin (eds.), Entre civitas y madina. El mundo de las ciudades en la Península Ibérica y en el norte de Africa (siglos IV-IX), (Madrid, 2018) 119-132.

Corpus Scriptorum Mozarabicorum, ed. Juan Gil (Madrid, 1973).

Cressier, Patrice, Chapiteaux de la grande mosquée de Cordoue (oratoires d'Abd ar-Rahman I et d'Abd ar-Rahman II) et la sculpture de chapiteaux à l'époque émirale, Madrider Mitteilungen 25 (1984) 216-281 and 26 (1985) 257-313.

Crónica del moro Rasis, versión del ajbār mulūk al-Andalus de Ahmad ibn Muhammad ibn Müsà al-Rāzì, 889-955. Romanzada para el rey don dionís de Portugal hacia el 1300 por Mahomad, Alarife y Gil Pérez, clérigo de don perianes porçel, ed. Diego Catalán and María Soledad De Andrés (Madrid, 1975).

Chronica gothorum pseudo-isidoriana, ed. Theodor Mommsen, in vol. XI, Chronica Minora, vol. 2, (Berlín, 1894), 378-388 and La chronica gothorum pseudo-isidoriana (ms. París BN 6113), ed. and trans. Fernando González Muñoz (A Coruña, 2000). 
Daiber, Hans, Orosius "Historiae adversus paganos « in arabischer Überlieferung, in: J. W. van Henten, H. J. de Jonge, P. T. van Rooden and J. W. Wesselius (eds.), Tradition and ReInterpretation in Jewish and in Early Christian Literature. Essays in Honour of J. C. H. Lebram (Leiden, 1986) 202-249.

David, Pierre, Annales Portugalenses Veteres, Études historiques sur la Galice et le Portugal du vie au XIIe siècle (Lisboa: 1947) 291-310.

Dhikr bilad al-Andalus. Una descripción anónima de al-Andalus, ed. and Spanish translation Luis Molina, 2 vols., (Madrid, 1983).

Di Branco, Marco, Storie arabe di Greci e di Romani. La Grecia e Roma negli storici arabi medieval (Pisa, 2009).

El Daly, Okasha, Egyptology. The Missing Millennium, Ancient Egypt in Medieval Arabic Writings (London, 2005).

Eger, Christoph, Frühislamische Bestattungen in Munigua, Archäologisches Korrespondenzblatt 46 (2016) 255-269.

Einhard, Vita Caroli, in: Scriptores rerum Germanicarum, col. Monumenta Germaniae Historica (Berlin: 1911).

Elices Ocón, Jorge El pasado preislámico en al-Andalus. Fuentes árabes, recepción de la antigüedad $y$ legitimación en época omeya (ss. VIII-X). Unpublished $\mathrm{PhD}$ thesis (Universidad Autónoma de Madrid, 2017). Accessed on 17 May 2019: repositorio.uam.es/handle/10486/679950.

Escalona, Julio, Family Memories. Inventing Alfonso I of Asturias, in: Isabel Alfonso, Hugh Kennedy, Julio Escalona (eds.), Building Legitimacy. Political Discourses and Forms of Legitimation in Medieval Societies (Leiden, 2004), 223-262.

Faro Carballa, José Antonio, María García-Barberena Unzu, Mercedes Unzu Urmeneta, Pamplona y el Islam nuevos testimonios arqueológicos, Trabajos de arqueología Navarra 20 (2007-2008) 229-284.

Fath al-Andalus, ed. Luis Molina, Fuentes Arábico-Hispanas 18 (Madrid, 1994). Spanish translation: Mayte Penelas, La conquista de al-Andalus. Fuentes Arábico-Hispanas 28 (Madrid, 2002).

Ferrero Hernández, Cándida, Cristianos y musulmanes en la Historia Arabum de Rodrigo Jiménez de Rada, The Journal of Medieval Latin 18 (2008) 356-373.

Fierro, Maribel, Madinat al-Zahara', el paraíso y los fatimíes, Al-Qantara 25/2 (2004) 299328.

Fontaine, Jaques, Un sarcófago cristiano de Córdoba, coetáneo de Osio, Archivo Español de Arte y Arqueología 20 (1947) 96-121.

García García, Miguel Ángel, La reutilización y destrucción de los sarcófagos romanos de Baetica durante la edad media, Romula 3 (2004) 239-256.

García Sanjuán, Alejandro, Territorio y formas de identidad colectiva en al-Andalus (siglos VIII-XV), Minervae Baeticae. Boletín de la Real Academia Sevillana de Buenas Letras, $\mathbf{2}^{\underline{a}}$ época, 43 (2015) 123-144.

Gil Fernández, Juan, José L. Moralejo and Juan I. Ruiz de la Peña, Crónicas asturianas (Oviedo, 1986).

Gleize Yves, Fanny Mendisco, Marie-Hélène Pemonge, Christophe Hubert, Alexis Groppi and Bertrand Houix (eds.), Early medieval Muslim graves in France. First archaeological, anthropological and palaeogenomic evidence, PLoS ONE 11 (2016). Accessed on 2 September 2019: journals.plos.org/plosone/article?id=10.1371/journal.pone.0148583. 
Gonzalo Maeso, David, Inscripción árabe de Carranque, in Carranque: centro de Hispania romana: Museo Arqueológico Regional, Alcalá de Henares, 27 de abril a 23 de septiembre de 2001 (Alcalá de Henares, 2001).

Gutas, Dimitri, Greek Thought, Arabic Culture. The Greco-Arabic Translation Movement in Baghdad and Early Abbasid Society (2-4/8-10 Centuries), (London, 1998).

Hen, Yitzhak and Innes, Matthew, The Uses of the Past in the Early Middle Ages (Cambridge, 2009)

Ibn Ḥabīb, Kitāb al-Ta’'īj, ed. Jorge Aguadé (Madrid, 1991).

Ibn Ḥayyān, Muqtabis V, ed. P. Chalmeta, F. Corriente and M. Șubḥ (Madrid, 1979). Spanish translation: Ma . J. Viguera and F. Corriente, Ibn Hayyān, de Cordoba. Crónica del califa Abderrahman III an-Nasir entre los años 912 y 942 (al-Muqtabis V) (Zaragoza, 1981).

Ibn Jaldūn, Ta'rīj Ibn Jaldūn al-musammà bi-Kitäb al-'Ibar wa-dìwān al-mubtada' wa-l-jabar fì ayyām al'arab wa-l-'aŷam wa-l-barbar wa-man 'āṣara-hun min dِawì l-sulțān al-akbar, ed. Y. A. Dagir (Beirut, 1956-1961).

Ibn Ŷulŷul, Les générations des médecins et des sages (Ṭabaqāt al-ațibbä' wa-l-hukamä'), ed. Fuad Sayyid (Cairo, 1955).

Isidore of Seville, Chronica maiora, ed. Theodor Mommsen, in col. Monumenta Germaniae Historica. Scriptores. Auctores Antiquissimi 11, (Berlin, 1894), 424-481.

Isidore of Seville, Etymologiae, ed. and trans. José Oroz Reta y Manuel Antonio Marcos Casquero, col. Biblioteca de Autores Cristianos 433, 2 vols., (Madrid, 1982).

Isidore of Seville, Historia Gothorum, ed. and trans. Cristóbal Rodríguez Alonso, Las Historias de los Godos, Vándalos y Suevos de Isidoro de Sevilla, (León, 1975).

Isla Frez, Amancio, Consideraciones sobre la monarquía astur, Hispania 55 (1995) 151-168.

Isla Frez, Amancio, Monarchy and neogothicism in the Astur Kingdom, 711-910, Francia 26/1, (1995), 41-56.

Jerome, The Chronicle of St. Jerome, ed. and trans. Roger Pearse, et al., in: The Tertullian Project: Early Church Fathers: Additional Texts (2005). Available at: www.tertullian.org/ fathers/jerome_chronicle_oo_eintro.htm

Jiménez de Rada, Rodrigo De rebus Hispaniae, ed., Juan Fernández Valverde, Corpus Christianorum (Turnhout, 1987).

Juan de Bíclaro, Chronica a. DLXVII-DXC, ed., Theodor Mommsen, in col. Monumenta Germaniae Historica. Scriptores. Auctores Antiquissimi 11 (Berlin, 1894), 207-220.

Juan García, Antonio de, Enterramientos medievales en el circo romano de Toledo. Estudio tipológico, in: Actas del I Congreso de Arqueología Medieval Española III, (Zaragoza, 1986) 641-654.

Julian, Sant, Sancti Iuliani Toletani sedis episcopi opera, ed. Jocelyn N. Hillgarth, (Turnhout, 1976).

Kitāb Hurūshiyūs. Traducción árabe de las "Historiae adversus paganos" de Orosio, ed. Mayte Penelas (Madrid, 2001).

La Rocca, Cristina, Using the Roman past. Abandoned towns and local power in the eleventhcentury Piemonte, Early medieval Europe 5 (1996), 54-69.

Levi della Vida, Giorgio, La traduzione araba delle Storie di Orosio, al-Andalus 19 (1954) 257293.

Manzano Moreno, Eduardo, Conquistadores, emires y califas. Los omeyas y la formación de al-Andalus (Barcelona, 2006).

McKitterick, Rosamund, History and Memory in the Carolingian World (Cambridge, 2004).

Al-Maqrizī, Kitāb al-mawā'iz wa'l-i'tibār fì dhikr al-khițaț wa'l-äthār (Al-Khițat), ed. Gaston Wiet (Cairo, 1911). 
Marsham, Andrew, Universal histories in Christendom and the Islamic World (c. 700-1400), in: Sarah Foot and Chase F. Robinson (eds.), The Oxford History of Historical Writing 2 (Oxford, 2015), 431-456.

Martínez-Gros, Gabriel, L’idéologie omeyyade. La construction de la légitimité du Califat de Cordoue (Xe-XIe siècles) (Madrid, 1992).

Molina, Luis, Sobre la procedencia de la Historia preislámica inserta en la Crónica del moro Rasis, Awraq V-VI (1982-3) 133-139.

Molina, Luis, The Muslim Conquest of Iberia. Medieval Arabic Narratives by Nicola Clarke. Reviewed in: Al-Qantara 35/2 (2014) 607-613.

Molina, Luis, Orosio y los geógrafos hispanomusulmanes, Al-Qantara 5 (1984) 63-92.

Murillo Redondo, Juan, La almunia de al-Rușāfa, Madrider Mitteilungen 50 (2009) 449-482.

Ocaña Jiménez, Manuel, El cúfico hispano y su evolución (Madrid, 1970).

Orosius, Historiae adversus paganos. Histoires (contre les Païens), ed. and trans. by Marie-Pierre Arnaud-Lindet, 3 vols. (Paris, 1990).

Picard, Christopher, Le passé antique et l' histoire d' al-Andalus chez les auteurs árabes, Pallas 63 (2003) 97-106.

Pizarro Berengena, G., El abastecimiento de agua a Córdoba, Arqueología e Historia. Unpublished PhD thesis (Universidad de Córdoba, 2013). Accessed on 11 August 2019: helvia. uco.es/xmlui/handle/10396/8623.

Rosenthal, Franz, The Classical Heritage in Islam [trans. from: Das Fortleben der Antike im Islam] (London, 1975).

Sáez Preciado, María Pilar, Últimas actuaciones realizadas en la ermita de Nuestra Señora de los Arcos (Tricio, La Rioja), Estrato 10 (1999) 11-19.

Safran, Janina M., The Second Umayyad Caliphate. The Articulation of Caliphal Legitimacy in al-Andalus (Cambridge, 2000).

Sahner, Christian, From Augustine to Islam. Translation and History in the Arabic. Orosius, Speculum 88 (2013) 905-931.

Schnapp, Alain, Lothar von Falkenhausen, Peter N. Miller and Tim Murray (eds.), World Antiquarianism. Comparative Perspectives (Los Angeles, 2013).

Shaw, Wendy, Possessors and Possessed. Museums, Archaeology, and the Visualization of History in the Late Ottoman Empire (Berkeley, 2003).

Sotomayor Muro, Manuel Datos históricos sobre los sarcófagos romano-cristianos de España (Granada, 1973).

Stylow, Armin U., Nuevo gobernador de la Bética del siglo IV, Gerión 18 (2000) 425-437.

Testamentum regis Adefonsi II, ed. Juan Ignacio Ruiz de la Peña and María Josefa Sanz Fuentes (Oviedo: 2005).

Tito Livio, Historia de Roma desde su fundación, vol., V: Libros XXVI-XXX, trans., José Antonio Villar Vidal (Madrid, 2001).

Torres Calzada, Katia, El emeritense. Noticia de la ciudad de Mérida recogida en el Iqtibās al-anwār de Abū Muhammad al-Rušāțī (466/1074-542/1147), Miscelánea de Estudios Árabes y Hebraicos. Sección Árabe-Islam 63 (2014) 233-256.

Utrero Aguado, María de los Ángeles and Issac Sastre de Diego, Reutilizando materiales en las construcciones de los siglos VII-X. Una posibilidad o una necesidad? Anales de Historia del Arte 22/2 (2012) 309-323.

Vallejo, Antonio, La ciudad califal de Madinat al-Zahrā'. Arqueología de su excavación (Córdoba, 2010). 
Vallejo, Antonio, Materiales de la Antigüedad en Madinat al-Zahra, in Carlos Márquez, (ed.) MÍMESIS: Imitación de los modelos clásicos y nuevos valores semánticos en el mundo tardoantiguo y medieval, (Córdoba, in press).

Vallvé, Joaquín, Fuentes latinas de los geógrafos árabes, al-Andalus 32 (1967) 241-260.

Ventura Villanueva, Ángel, Los acueductos romanos de Córdoba y su rehabilitación omeya, Empuries 53 (2002) 113-128.

Wasserstein, David, The library of al-Hakam II al-Mustansir and the culture of Islamic Spain, Manuscripts of the Middle East 5 (1990-1991) 99-105. 